\title{
Polymorphisms in the Bradykinin B2 Receptor Gene and Childhood Asthma
}

\author{
Beate Kusser ${ }^{1, \star}$, Andreas Braun², Manfred \\ Praun ${ }^{1}$, Sabina Illi ${ }^{1}$, Erika von Mutius ${ }^{1}$ and \\ Adelbert A. Roscher ${ }^{1}$ \\ ${ }^{1}$ Departments of Clinical Chemistry and Pulmonary \\ Disease, University Children's Hospital, Ludwig \\ Maximilians University, 80337 Munich, Germany \\ ${ }^{2}$ Sequenom, Inc., 3595 John Hopkins Court, San Diego, \\ CA 92121, USA \\ ${ }^{*}$ Corresponding author
}

Bradykinin has been suggested as one of the key mediators of bronchial asthma. Polymorphisms with a potential functional relevance have been described in the B2 bradykinin receptor gene. Study of these polymorphisms in 77 children with asthma and 73 controls revealed no association. However, when comparing the asthmatics according to their age at onset (before and after age 4), the exon 1 allele BE1-2G was significantly associated with late-onset asthma $(p<0.05)$. Since BE1-2G has previously been shown to lead to a higher transcription rate of the $\mathrm{B} 2$ receptor, this result warrants further investigation of the role of bradykinin in conferring susceptibility to pediatric asthma.

Key words: B2/BKR/Single nucleotide polymorphism / SNP.

The nonapeptide bradykinin (BK) has been suggested as one of the key mediators of bronchial asthma (Barnes, 1989). Elevated levels of bradykinin have been detected in the airways of asthmatics (Christiansen et al., 1992) and inhalation of bradykinin induces bronchoconstriction in asthmatics, but not in healthy controls (Polosa and Holgate, 1990). B2 bradykinin receptors (B2-BKR) on smooth muscle cells (Mak and Barnes, 1991), C-fibers (Fox et al., 1993), blood vessels (Ichinose and Barnes, 1990), mucous glands (Baraniuk et al., 1990) and endothelial cells (Mak and Barnes, 1991) have been suggested to mediate the effects of BK on bronchial constriction, edema formation and dyscrinism, respectively. In a placebo-controlled, randomized clinical trial, the selective B2-BKR-antagonist HOE 140 (Icatibant ${ }^{\circledR}$ ) acted as a potent anti-inflammatory drug in adult asthmatics (Akbary et al., 1996). While B2 receptors are constitutively expressed, B1 bradykinin-receptors are only induced in pathological states of the lung, and have thus also been suspected to be involved in lung disease (Nadar et al., 1996). In contrast to B2 receptors, however, there is no evidence for a functional role of B1 receptors in the pathogenesis of asthma so far.

Since childhood asthma is strongly associated with a positive family history of asthma and atopic disease (Frischer et al., 1993), a genetic background has long been suspected. Segregation studies have resulted in a polygenetic model of inheritance (Schork, 1997) and genome-wide linkage studies have - among others identified polymorphic markers on chromosome $14 \mathrm{q}$ to be associated with asthma (Ober et al., 2000). Among other candidate genes for an association with asthma, such as those for the mast cell chymase, for NFKB1 and for parts of the T cell receptor, both the B1- and the B2BKR gene have been localized on chromosome 14q (Kammerer et al., 1995).

Earlier reports from our group have described polymorphisms in the three exons of the B2 receptor gene, suggesting that they may be relevant for bradykinin-associated diseases (Braun et al., 1995). In exon 1, a tandem repeat polymorphism affecting the gene's transcription rate, has been identified. Among the 3 common alleles (2G, $3 T$ and $3 G$ ), the $2 G$ allele was associated with the highest and the $3 T$ allele with the lowest transcription rate. In exon 2, a C to T transition was found which results in an arginine to cysteine substitution (R14C), thereby potentially influencing the receptor's affinity and stability. In exon 3 , a more complex tandem repeat polymorphism with two common alleles, containing 43 and 33 repeat units, respectively, and two rare variants were identified. Situated in the non-coding 3'-region of exon 3, this polymorphism might affect the stability of the mRNA (Braun et al., 1996).

Clinical association studies have demonstrated an association between the B2-BKR exon 1 polymorphism and the clinical manifestation of angioedema in C1-esterase inhibitor deficiency (Lung et al., 1997). Studies of the B2-BKR exon 2 polymorphism in patients with end stage renal disease have so far produced conflicting results (Bachvarov et al., 1998; Zychma et al., 1999).

We have studied the polymorphisms in the three exons of the B2-BKR gene in 77 asthmatics and 73 controls from the University Children's Hospital in Munich, Germany. In order to eliminate ethnic confounding, the respective German subgroups (64 asthmatics, 56 controls) were also compared. There was a slight difference in age that was statistically significant $(p=0.0487)$ in the German subgroup, although median and range were the same as 
in the total sample (Table 1). As expected, we found significant differences in the distribution of known risk factors for childhood asthma, namely allergic rhinitis $(p<0.0001)$ and a family history of allergic rhinitis and atopic dermatitis $(p<0.01$, respectively). Atopic dermatitis was also significantly associated with asthma in the total sample $(p<0.05)$. In the smaller German subgroup, the difference was preserved in tendency $(28 \%$ in asthmatics versus $14 \%$ in controls), although not being significant $(p=0.08)$.

Genotype and allelic distributions were in accordance with Hardy Weinberg equilibrium in all groups as tested with the adapted $\chi^{2}$ test (Mueller and Clerget-Darpoux, 1991) (data not shown) and showed no significant differences between asthmatics and controls for all three exon polymorphisms (Table 2). Since there were no significant

Table 1 Clinical Characteristics of Asthmatics and Controls.

\begin{tabular}{|c|c|c|c|c|}
\hline Characteristics & $\begin{array}{l}\text { Asthmatics } \\
(\mathrm{n}=77)\end{array}$ & $\begin{array}{l}\text { Controls } \\
(n=73)\end{array}$ & $\begin{array}{l}\text { Statistical analysis } \\
\text { (whole group) }\end{array}$ & $\begin{array}{l}\text { Statistical analysis } \\
\text { (German group) }\end{array}$ \\
\hline Age & $9(2-17)$ & $8(1-17)$ & n.s. ${ }^{*}$ & $p<0,05$ \\
\hline Gender (female/male) & $27 / 50$ & 27 / 37 & n.s. & n.s. \\
\hline Allergic rhinitis & $25(32 \%)$ & $1(1 \%)$ & $p<0.0001$ & $p<0.0001$ \\
\hline Atopic dermatitis & 20 (26\%) & $8(11 \%)$ & $\mathrm{p}<0.05$ & n.s. \\
\hline $\begin{array}{l}\text { Family history of } \\
\text { allergic rhinitis }\end{array}$ & 42 (55\%) & $23(32 \%)$ & $p<0.01$ & $p<0.05$ \\
\hline $\begin{array}{l}\text { Family history of } \\
\text { atopic dermatitis }\end{array}$ & $42(55 \%)$ & $7(10 \%)$ & $p<0.01$ & $\mathrm{p}<0.01$ \\
\hline $\begin{array}{l}\text { Family history of } \\
\text { asthma }\end{array}$ & $42(55 \%)$ & excluded & not tested & not tested \\
\hline
\end{tabular}

${ }^{*}$ n.s. = not significant.

Age is given as median (range) and the number and percentage of carriers are listed for each risk factor. The age was compared using the Wilcoxon test, gender and risk factors were analyzed with the exact Fisher test. The statistical analysis was done for the whole group and the German group, respectively. Data were obtained through standardized questionnaires and informed consent was given by at least one parent. Children with asthma, wheezing bronchitis, recurrent bronchitis or a history of asthma and those with chronic disease or suspected or known inherited disease were excluded from the control group.

Table 2 Allelic Frequencies for the B2-BKR Gene in Asthmatics and Controls.

\begin{tabular}{lllll}
\hline Allele & $\begin{array}{l}\text { Asthmatics } \\
(n=77)\end{array}$ & $\begin{array}{l}\text { Controls } \\
(n=73)\end{array}$ & $\begin{array}{l}\text { Exact } \\
\text { Fisher test }\end{array}$ & $\begin{array}{l}\text { Monte Carlo } \\
\text { test }\end{array}$ \\
\hline BE1-2G & 0.533 & 0.500 & & \\
BE1-3T & 0.266 & 0.356 & n.s. & n.s. \\
BE1-3G & 0.201 & 0.144 & & n.s. \\
BE2-C & 0.916 & 0.925 & n.s. & \\
BE2-T & 0.084 & 0.075 & & n.s. \\
BE3-R43 & 0.851 & 0.863 & & \\
BE3-R33 & 0.117 & 0.103 & n.s. & \\
BE3-var & 0.032 & 0.034 & & \\
\hline
\end{tabular}

${ }^{*}$ n.s. = not significant.

Allelic frequencies for polymorphisms in the three exons of the B2-BKR gene in asthmatics and controls. The statistical analysis with the exact Fisher test for allelic frequencies and the Monte Carlo test for associations between disease and alleles at highly polymorphic loci (Sham and Curtis, 1995), used for the comparison of the respective genotype distributions, were not significant (n.s.) in the whole group, the German group (64 asthmatics, 56 controls) and the 'atopic' group (69 atopic asthmatics, 73 controls).

The polymorphism in exon 1 was shown by single-strand conformational polymophism (SSCP) analysis in a 10\% polyacrylamide gel buffered with $0.5 \times$ TBE. Electrophoresis in $1 \mathrm{x}$ TBE buffer at $120 \mathrm{~V}$ for $12 \mathrm{~h}$ produced additional heteroduplex bands for better differentiation of heterozygote carriers of $2 \mathrm{G}$ from homozygous carriers of $3 G$ and $3 T$ compared with the conditions described previously. The polymorphism in exon 2 was detected by gel electrophoresis after digestion with restriction endonuclease Taql and the exon 3 polymorphism by gel electrophoresis directly, both as previously described (Braun et al., 1995). 
associations, genotype distributions and data for the respective subgroups are not listed separately.

In order to account for potential pathogenetic differences, the asthma group was stratified into subgroups with an onset of symptoms before $(n=31$, early onset asthmatics) and after the age of 4 years ( $n=46$, late onset asthmatics). Risk factors were similar in both groups with a non-significant trend towards a higher frequency of atopic dermatitis in the early onset and of allergic rhinitis in the late onset group. This may, however, be explained by differences in the median age (10 versus 8 years). There was also a slightly higher proportion of girls in the late onset group, that was not statistically significant (Table 3). Similar results were obtained in the German group comparing 28 early-onset and 36 late-onset asthmatics.

There was a significantly higher frequency of the exon 1 allele BE1-2G in the late onset group ( $p<0.05$; Table 4). In the smaller German group, this association did not reach statistical significance $(p=0.09)$, but the magnitude of difference between the allelic frequencies remained almost the same ( 0.168 versus 0.190$)$. The loss of significance may thus be attributed to the reduced sample size (28 early- and 36 late-onset asthmatics), rather than a false positive association due to ethnical differences. Apart from the allele BE1-2G, the statistical analyses showed no significant association in the complete group and in the German subgroup (Table 4).

Table 3 Clinical Characteristics of Early and Late Onset Asthmatics.

\begin{tabular}{|c|c|c|c|}
\hline Risk factor & $\begin{array}{l}\text { Early onset } \\
(n=31)\end{array}$ & $\begin{array}{l}\text { Late onset } \\
(n=46)\end{array}$ & $\begin{array}{l}\text { Statistical analysis } \\
\text { (Whole and German group) }\end{array}$ \\
\hline Age & $8(2-15)$ & $10(4-17)$ & n.s.* \\
\hline Gender (girls/boys) & $9 / 22$ & $18 / 28$ & n.s. \\
\hline Allergic rhinitis & $8(26 \%)$ & $17(37 \%)$ & n.s. \\
\hline Atopic dermatitis & $10(32 \%)$ & $10(22 \%)$ & n.s. \\
\hline Atopy (lgE>100 kU/l) & $29(94 \%)$ & $40(87 \%)$ & n.s. \\
\hline $\begin{array}{l}\text { Family history of } \\
\text { asthma }\end{array}$ & $19(61 \%)$ & $23(50 \%)$ & n.s. \\
\hline $\begin{array}{l}\text { Family history of } \\
\text { allergic rhinitis }\end{array}$ & $19(61 \%)$ & $23(50 \%)$ & n.s. \\
\hline $\begin{array}{l}\text { Family history of } \\
\text { atopic dermatitis }\end{array}$ & $8(26 \%)$ & $14(30 \%)$ & n.s. \\
\hline
\end{tabular}

${ }^{*}$ n.s. = not significant.

Age, gender and risk factors for childhood asthma in early and late onset asthmatics. The age is given as median (ranges). For the risk factors, the number and percentage of subjects carrying the respective risk factor are listed. The age was compared using the Wilcoxon test, gender and risk factors were analyzed with the exact Fisher test. The statistical analysis was done for the whole group and the German group (28 early-onset and 36 lateonset asthmatics), respectively.

Table 4 Allelic Frequencies for the B2-BKR Gene in Early and Late Onset Asthmatics.

\begin{tabular}{llllllll}
\hline & Whole group & \multicolumn{5}{c}{ German group } \\
\hline Alleles & $\begin{array}{l}\text { Early onset } \\
(\mathrm{n}=31)\end{array}$ & $\begin{array}{l}\text { Late } \\
\text { onset } \\
(\mathrm{n}=46)\end{array}$ & $\begin{array}{l}\text { Exact } \\
\text { Fisher } \\
\text { test }\end{array}$ & $\begin{array}{l}\text { Early onset } \\
(\mathrm{n}=28)\end{array}$ & $\begin{array}{l}\text { Late } \\
\text { onset } \\
(\mathrm{n}=36)\end{array}$ & $\begin{array}{l}\text { Exact } \\
\text { Fisher } \\
\text { test }\end{array}$ & $\begin{array}{l}\text { Monte } \\
\text { Carlo } \\
\text { test }\end{array}$ \\
\hline BE1-2G & 0.419 & 0.609 & $\mathrm{p}=0.034$ & 0.429 & 0.597 & $\mathrm{n} . \mathrm{s}^{*}$ & \\
BE1-3T & 0.306 & 0.239 & n.s. & 0.304 & 0.236 & n.s. & n.s. \\
BE1-3G & 0.274 & 0.152 & n.s. & 0.268 & 0.166 & n.s. & \\
BE2-C & 0.935 & 0.902 & n.s. & 0.929 & 0.889 & n.s. & n.s. \\
BE2-T & 0.065 & 0.098 & n.s. & 0.071 & 0.111 & n.s. & \\
BE3-R43 & 0.903 & 0.815 & n.s. & 0.893 & 0.819 & n.s. & n.s. \\
BE3-R33 & 0.065 & 0.152 & n.s. & 0.071 & 0.167 & n.s. & n.s. \\
BE3-var & 0.032 & 0.033 & n.s. & 0.036 & 0.014 & n.s. \\
\hline
\end{tabular}

${ }^{*}$ n.s. $=$ not significant. 
A number of diseases in childhood are associated with wheezing, but are not necessarily asthma (Silverman, 1993) and the recruitment of non-asthmatic wheezers is a potential pitfall for any study on pediatric asthma. In a large prospective study following children from birth until the age of 6 years, three major types of wheezing have been identified: transient early wheezing occurring in infants until the age of 3 years, persistent wheezing up to at least 6 years of age and late-onset wheezing starting after the age of 3 years (Martinez et al., 1995). Only persistent and late onset wheezing were associated with atopy, atopic dermatitis, allergic rhinitis and maternal asthma. We tried to eliminate transient early wheezers from our study group by recruiting - with one exception - only patients over 4 years of age. Recently, another type of persistent wheezers has been described, with symptoms up to early school years, that are usually not accompanied by atopy and bronchial hyperresponsiveness, and do not progress to chronic bronchial asthma (Martinez and Helms, 1998). The fact that $90 \%$ of our patients were atopic may thus indicate that we have not recruited a major proportion of these patients, although it cannot be excluded with certainty.

As the control group was recruited from our general pediatric clinic, a selection bias towards children with premorbidities needed to be considered. We have tried to minimize this potential bias by excluding all children with chronic disease and with suspected or known inherited disease. We have also excluded all children with a family history of asthma from the control group, but some had a family history of allergic rhinitis (30\%) or atopic dermatitis $(10 \%)$ and a few children were suffering from one or both of these diseases (Table 1). An atopic disposition may thus have been present in a part of our control group, although this did not exceed the proportion in the general population. Additionally, since we have attempted to study genetic markers for asthma and not for atopy, this should not necessarily have affected our results.

Because the distribution of the B2 receptor polymorphisms depends on ethnicity (Lung et al., 1997), we have only recruited Caucasians in the study and have separately compared the respective German groups to rule out ethnical confounding. We have observed a loss of significance for atopic dermatitis and for the association of late onset asthma with the allele $2 \mathrm{G}$ in the German groups. However, this is most likely due to reduced numbers and can hardly be attributed to ethnic differences.

Different pathogenetic models have been associated with the age of onset in pediatric asthma (Martinez and Helms, 1998). Interestingly, we found an association of late-onset asthma with the exon 1 allele $2 \mathrm{G}$, which had earlier been associated with a relatively increased transcription rate of the B2 receptor (Braun et al., 1996). This is consistent with the hypothesis that bradykinin may be more important in the pathogenesis of late onset than of early onset asthma. However, larger studies will be necessary to reproduce and specify this association.

Since the exon 1 polymorphism is associated with the transcription rate of the $\mathrm{B} 2$ receptor gene, it is tempting to speculate that the exon 1 polymorphism could identify a subgroup of patients who might benefit from a different therapeutic approach. In view of the selective B2 antagonists that are now available, patients with a higher transcription rate of the $B 2$ receptor gene, namely carriers of the $2 \mathrm{G}$ allele, may form a promising target for the clinical use of these new drugs.

In summary, we have found a weak association between late-onset pediatric asthma and the exon 1 allele $\mathrm{BE} 1-2 \mathrm{G}$ of the $\mathrm{B} 2$ bradykinin receptor gene. Because pediatric asthma is a complex disease with a polygenetic background and strong environmental influences, large or appropriately stratified cohorts will be needed to confirm and specify this association.

\section{Acknowledgements}

We thank Esther Maier for technical assistance, Bertram MüllerMysok for special statistical support, and Wulf Röschinger for actively supporting the recruitment of the control group.

\section{References}

Akbary, A.M., Wirth, K.J., and Scholkens, B.A. (1996). Efficacy and tolerability of Icatibant (HOE 140) in patients with moderately severe chronic bronchial asthma. Immunopharmacology 33, 238-242.

Bachvarov, D.R., Landry, M., Pelletier, I., Chevrette, M., Betard, C., Houde, L., Bergeron, J., Lebel, M., and Marceau, F. (1998). Characterization of two polymorphic sites in the human kinin B1 receptor gene: altered frequency of an allele in patients with a history of end-stage renal failure. J. Am. Soc. Nephrol. 9, 598-604.

Baraniuk, J.N., Lundgren, J.D., Mizoguchi, H., Peden, D., Gawin, A., Merida, M., Shelhamer, J.H., and Kaliner, M.A. (1990). Bradykinin and respiratory mucous membranes. Analysis of bradykinin binding site distribution and secretory responses in vitro and in vivo. Am. Rev. Respir. Dis. 141, 706-714.

Barnes, P.J. (1989). New concepts in the pathogenesis of bronchial hyperresponsiveness and asthma. J. Allergy Clin. Immunol. 83, 1013-1026.

Braun, A., Kammerer, S., Bohme, E., Muller, B., and Roscher, A.A. (1995). Identification of polymorphic sites of the human bradykinin B2 receptor gene. Biochem. Biophys. Res. Commun. 211, 234-240.

Braun, A., Kammerer, S., Maier, E., Bohme, E., and Roscher, A.A. (1996). Polymorphisms in the gene for the human B2bradykinin receptor. New tools in assessing a genetic risk for bradykinin-associated diseases. Immunopharmacology 33, 32-35.

Christiansen, S.C., Proud, D., Sarnoff, R.B., Juergens, U., Cochrane, C.G., and Zuraw, B.L. (1992). Elevation of tissue kallikrein and kinin in the airways of asthmatic subjects after endobronchial allergen challenge. Am. Rev. Respir. Dis. 145, 900-905.

Fox, A.J., Barnes, P.J., Urban, L., and Dray, A. (1993). An in vitro study of the properties of single vagal afferents innervating Guinea pig airways. J. Physiol. 469, 21-35.

Frischer, T., Kuehr, J., Meinert, R., Karmaus, W., and Urbanek, R. (1993). Risk factors for childhood asthma and recurrent wheezy bronchitis. Eur. J. Pediatr. 152, 771-775. 
Ichinose, M., and Barnes, PJ. (1990). Bradykinin-induced airway microvascular leakage and bronchoconstriction are mediated via a bradykinin B2-receptor. Am. Rev. Respir. Dis. 142, $1104-1107$.

Kammerer, S., Braun, A., Arnold, N., and Roscher, A.A. (1995). The human bradykinin $B 2$ receptor gene: full length cDNA, genomic organization and identification of the regulatory region. Biochem. Biophys. Res. Commun. 211, 226-233.

Lung, C.C., Chan, E.K., and Zuraw, B.L. (1997). Analysis of an exon 1 polymorphism of the B2 bradykinin receptor gene and its transcript in normal subjects and patients with $\mathrm{C} 1$ inhibitor deficiency. J. Allergy Clin. Immunol. 99, 134-146.

Mak, J.C., and Barnes, P.J. (1991). Autoradiographic visualization of bradykinin receptors in human and Guinea pig lung. Eur. J. Pharmacol. 194, 37 - 43.

Martinez, F.D., and Helms, P.J. (1998). Types of asthma and wheezing. Eur. Respir. J. 27 (Suppl.), 3s-8s.

Martinez, F.D., Wright, A.L., Taussig, L.M., Holberg, C.J., Halonen, M., and Morgan, W.J. (1995). Asthma and wheezing in the first six years of life. The Group Health Medical Associates. N. Engl. J. Med. 332, 133-138.

Muller, B., and Clerget-Darpoux, F. (1991). A test based on the exact probability distribution of the chi 2 statistic - incorporation into the MASC method. Ann. Hum. Genet. 55, 69- 75.

Nadar, R., Derrick, A., Naidoo, S., Naidoo, Y., Hess, F., and Bhoola, K. (1996). Immunoreactive B1 receptors in human transbronchial tissue. Immunopharmacology 33, 317-320.
Ober, C., Tsalenko, A., Parry, R., and Cox, N.J. (2000). A secondgeneration genomewide screen for asthma-susceptibility alleles in a founder population. Am. J. Hum. Genet. 67, $1154-1162$.

Polosa, R., and Holgate, S.T. (1990). Comparative airway responses to inhaled bradykinin, kallidin and (desArg9)bradykinin in normal and asthmatics subjects. Am. Rev. Respir. Dis. 142, 1367-1371.

Schork, N.J. (1997). Genetics of complex disease: approaches, problems, and solutions. Am. J. Respir. Crit. Care Med. 156, S103-S109.

Sham, P.C., and Curtis, D. (1995). Monte Carlo tests for associations between disease and alleles at highly polymorphic loci. Ann. Hum. Genet. 59, 97-105.

Silverman, M. (1993). Out of the mouths of babes and sucklings: lessons from early childhood asthma. Thorax 48, 1200-1204.

Zychma, M.J., Gumprecht, J., Zukowska-Szczechowska, E., and Grzeszczak, W. (1999). Polymorphisms in the genes encoding for human kinin receptors and the risk of end-stage renal failure: results of transmission/disequilibrium test. The End-Stage Renal Disease Study Group. J. Am. Soc. Nephrol. $10,2120-2124$.

Received January 2, 2001; accepted February 5, 2001 